\title{
Why do some women micro-entrepreneurs decide to formalise their businesses?
}

\section{Carla Susana Marques* and Carmem Teresa Leal}

Department of Economics, Sociology and Management, CETRAD Research Unit,

University of Trás-os-Montes e Alto Douro,

Quinta de Prados, 5000-801 Vila Real, Portugal

Email: smarques@utad.pt

Email: cleal@utad.pt

*Corresponding author

\section{Gina Santos}

University of Trás-os-Montes e Alto Douro, Quinta de Prados, 5000-801 Vila Real, Portugal

Email: gina.santos@utad.pt

\section{Carlos Peixeira Marques}

Department of Economics, Sociology and Management, CETRAD Research Unit,

University of Trás-os-Montes e Alto Douro,

Quinta de Prados, 5000-801 Vila Real, Portugal

Email: cmarques@utad.pt

\section{Roberta Alves}

University of Trás-os-Montes e Alto Douro, Quinta de Prados, 5000-801 Vila Real, Portugal

Email: psi.roberta@yahoo.com.br

\begin{abstract}
The present study intends to identify the profile of women microentrepreneurs and assess the extent to which their entrepreneurial motivations may be influenced by legal incentives to formalise their businesses and by their capacity to reconcile the demands of family and work. A questionnaire was used to gather data on the individual entrepreneurial initiatives of women in Brazil. We evaluated multiple linear regression models for their explanation of the dimensions involving motivations to formalise business activities and dual roles as workers and homemakers, as well as using cluster analysis to identify the profile of women micro-entrepreneurs. The results suggest that these women opt for legalised individual entrepreneurship to access the benefits offered by the formalisation of their businesses and to search for mechanisms that encourage a work-family balance.
\end{abstract}


Keywords: women entrepreneurs; profile; motivations; work-family balance; business formalisation; micro-entrepreneur law; Brazil.

Reference to this paper should be made as follows: Marques, C.S., Leal, C.T., Santos, G., Marques, C.P. and Alves, R. (2017) 'Why do some women micro-entrepreneurs decide to formalise their businesses?', Int. J. Entrepreneurship and Small Business, Vol. 30, No. 2, pp.241-258.

Biographical notes: Carla Susana Marques has a PhD in Management. She is Assistant Professor in the University of Trás-os-Montes e Alto Douro (UTAD) and Coordinator of the 'Innovation, Markets and Organization' research group in UTAD's Centre for Transdisciplinary Development Studies. Her research on innovation and entrepreneurship has been presented at numerous international conferences and published in international journals.

Carmem Teresa Leal has a Master (2004) and PhD (2011) degrees in Management by UTAD. She is an Assistant Professor of Knowledge Management at University of Trás-os-Montes e Alto Douro. Her research on knowledge management (intellectual capital) has been presented at numerous international conferences. At the moment her research focuses on knowledge management within enterprises' performance.

Gina Santos has a Master's degree in Management (UTAD, 2011). In her Master's in Management she characterised and related the profile, the duplication of women's roles, motivations and environment (rural vs. urban) of the Portuguese entrepreneurial woman. Currently her research interests include entrepreneurship, strategy, gender and the implications of innovation for organisational and institutional change.

Carlos Peixeira Marques is currently the Director of the degree in Tourism of the University of Trás-os-Montes e Alto Douro (UTAD). He holds a degree in Sociology, a MBA and a PhD in Management, and his research focuses on the attitudes and behaviour of managers, employees, and consumers.

Roberta Alvesis a Master's student in Management (UTAD). Her research interests include entrepreneurship and gender and its implications in economy.

\section{Introduction}

Gender entrepreneurship is an area of study that has developed since the 1970s, having emerged as an area of academic research especially from the early 80 s onwards (Henry et al., 2015). Early studies appeared in the USA in the mid-70s, focusing on the differences between male and female entrepreneurs regarding their psychological and sociological characteristics (Schreier, 1975; Schwartz, 1976). Women entrepreneurship research has gone from its purely exploratory and descriptive first studies to a field where increasingly specialised studies are found (Carter and Shaw, 2006). This issue has become a major focus of interest to academics, politicians and other stakeholders connected to entrepreneurship (Henry, 2007). Carter et al. (2001), Greene et al. (2003), Carter and Shaw (2006), Brush et al. (2009), Holmquist and Carter (2009), Gatewood et al. (2009) and Hughes et al. (2012) are studies we consider important when seeking to contextualise female entrepreneurship research. 
Currently, gender entrepreneurship research is on the threshold of its 'adolescence' stage (Hughes et al., 2012; Henry et al., 2015). According to the cited authors, the main indicators of its rapid expansion are the growing number of conferences, relevant publications' special editions or even reports dealing with international standards [e.g., global entrepreneurship monitor (GEM)], among other factors.

Cromie (1987) and Hisrich (1989) present other possible factors in the emergence of this theme. These authors suggest that women create their own businesses in search of independence and, in the process, overcome difficulties in moving up the career ladder in other people's companies and enjoy the convenience of this specific business model for reconciling work and family, as well as satisfying other motivations. Given this desire for independence, in Brazil, the economic potential of women's entrepreneurship has become significant in the formal and informal sphere (OECD, 1998). Many studies posit that the informal sector is well tailored to the needs of women entrepreneurs because it provides greater flexibility in terms of working hours, pace of work and proximity of the job to home (e.g., Babbitt et al., 2015). An informal business framework has always existed in Brazil, and, in 2006, in order to formalise millions of enterprises that were on the margins of society, Supplementary Law 123/06 established the groundwork for the legal existence of 'individual micro-entrepreneurs' (IMEs) (SEBRAE, 2011). Since Supplementary Law $123 / 06$ was passed, many men and women have had the opportunity to formalise their ventures, for which these entrepreneurs are granted special treatment, quick registration, immediate access to the national register of legal entities and easy access to financial support (SEBRAE, 2012).

Since this legislation entered into force, 3.6 million entrepreneurs have already been formalised (SEBRAE, 2014), and the number of IMEs is expected to become larger than micro and small enterprises (SEBRAE, 2012). As reported by GEM (2013), women's share in entrepreneurship in 2002 accounted for $40 \%$ of all such businesses. Notably, in 2012 , their share was higher at $52 \%$, thus falling by more than $20 \%$ in one year. For women, entrepreneurship is an alternative way to reconcile natural needs because of its flexible working hours and it is a great source of satisfaction (Ford, 2007). The opening of new businesses that have identified new opportunities for products and services is one of the main frontiers of female entrepreneurship (SEBRAE, 2012).

After this short introduction of the focus of our study, we can now present the goal of this research paper: to characterise and describe the profile, motivations and reasons for formalisation of IME businesses of women micro-entrepreneurs of Vitória da Conquista, Brazil. To achieve this goal, this paper is structured as follows. After the introduction, we provide a theoretical discussion of the psychological attributes that motivate women to become entrepreneurs, in order to find a work-family balance and satisfy other needs. After some contextual considerations, the methodology is presented, followed by the research results. Finally, we conclude with a discussion of this study's main limitations, implications for management practice and potential future opportunities of research.

\section{Profile and motivations of individual women micro-entrepreneurs}

\subsection{Profile}

Research on the psychological characteristics of entrepreneurs - regardless of gender began to emerge in the 40 s with a study by Schumpeter (1942). Since then, many 
researchers have contributed to the development of the literature on this area (e.g., McClelland, 1961; Kourilsky, 1980; Sexton and Bowman, 1986; Hisrich and Peters, 2004; Zhao and Seibert, 2006; Raposo et al., 2008; Marques et al., 2011b).

Specific studies of the psychological characteristics of women entrepreneurs took place in the 70s, including Schreier (1975) and Schwartz's (1976) studies researching the differences between women and men entrepreneurs. Since then, this area has attracted the interest of many other researchers, such as Sexton and Kent (1981), Hisrich and O'Brien (1982), Hisrich and Brush (1984), Goffee and Scase (1985), Sexton and Bowman (1986), Watkins and Watkins (1986), Lee-Gosselin and Grise (1990), Brush (1992), Segal et al. (2005), Bruin et al. (2007) and Marques et al. (2011a).

Table 1 Gender-based psychological and cognitive traits

\begin{tabular}{|c|c|c|}
\hline Key references & $\begin{array}{c}\text { Gender-based psychological } \\
\text { differences }\end{array}$ & Gender-based cognitive differences \\
\hline \multirow[t]{2}{*}{$\begin{array}{l}\text { Sexton and } \\
\text { Bowman-Upton } \\
(1990)\end{array}$} & $\begin{array}{l}\text { Autonomy/openness to change: } \\
\text { women entrepreneurs' value } \\
\text { autonomy more, has a greater } \\
\text { propensity to seek out change/new } \\
\text { experiences and more readily } \\
\text { adjust their values/opinions. }\end{array}$ & $\begin{array}{l}\text { Physical energy/resilience: women } \\
\text { entrepreneurs' energy levels are } \\
\text { lower in terms of activity, intensity, } \\
\text { reserves and stamina. }\end{array}$ \\
\hline & $\begin{array}{l}\text { Aversion to risk: women } \\
\text { entrepreneurs are more risk averse } \\
\text { than their male counterparts. }\end{array}$ & \\
\hline $\begin{array}{l}\text { Carland and } \\
\text { Carland (1991) }\end{array}$ & $\begin{array}{l}\text { Intuition: women tend to be } \\
\text { strongly intuitive, focusing on 'the } \\
\text { big picture' rather than on the } \\
\text { directly perceived reality on which } \\
\text { males concentrate. }\end{array}$ & $\begin{array}{l}\text { People-orientation: women's } \\
\text { views/actions are more 'people } \\
\text { oriented', with men being } \\
\text { ostensibly more 'logical', 'rational' } \\
\text { or 'thinking-oriented'. }\end{array}$ \\
\hline $\begin{array}{l}\text { Shaver et al. } \\
\text { (1996) }\end{array}$ & $\begin{array}{l}\text { Innovation: a significant difference } \\
\text { between women and men } \\
\text { entrepreneurs is evident in } \\
\text { innovation and } \\
\text { achievement/activity. }\end{array}$ & No cognitive differences discussed. \\
\hline $\begin{array}{l}\text { Marques et al. } \\
\text { (2011a) }\end{array}$ & $\begin{array}{l}\text { Self-esteem/autonomy: self-esteem } \\
\text { and the desire for greater autonomy } \\
\text { are the most significant } \\
\text { psychological factors motivating } \\
\text { female start-ups. }\end{array}$ & $\begin{array}{l}\text { Rigour in the resolution of } \\
\text { problems: 'rising to the challenge' } \\
\text { figures among key motivational } \\
\text { variables, with the cognitive } \\
\text { factor 'rigour' strongly correlated } \\
\text { with the psychological factor } \\
\text { 'self-esteem'. }\end{array}$ \\
\hline
\end{tabular}

According to Ahl (2004), while taking into account a number of psychological, behavioural and other background factors, the research indicates that more similarities than differences can be found between female and male entrepreneurs. However, major differences have been found between women entrepreneurs themselves, different professional groups (e.g., entrepreneurs and managers) and entrepreneurs from different countries. Although most studies do not indicate major differences between men and women, Table 1 presents some studies that highlight the distinctive psychological characteristics of female entrepreneurs.

Psychological attributes, per se, have always shown some limitations and ineffectiveness in these traits' ability to explain, for instance, the differences 
between entrepreneurs and non-entrepreneurs, mainly due to a lack of consensus around these attributes (Marques et al., 2011b). Nonetheless, according to the cited authors, cognitive factors have become the focus of complementary studies of entrepreneurs' characteristics, helping to map a much more detailed profile of entrepreneurs.

\subsection{Women and the work-family balance}

The conflict between work and family was a theme introduced by Kahn et al. in 1964 . The issue of finding a balance between family and work is a typically female problem (Marlow, 1997), both from a material perspective (e.g., dedicated time) and a psychological perspective (e.g., feelings, desires and fears). Some studies have suggested that, for 'working mothers', entrepreneurship provides greater flexibility in combining work responsibilities and household tasks (Caputo and Dolinsky, 1998). Women try to organise their time in order to avoid conflicts between their roles as a mother/wife and an entrepreneur.

In the present study, Hobfoll's (1989) theory of resource conservation was used to understand the nature of entrepreneurial work. This approach is useful as a way to understand the conditions under which the management of work-family conflict becomes difficult. According this theory, people seek to acquire and maintain resources, which can be material objects (e.g., housing, clothes and food), personal characteristics (e.g., self-esteem), conditions (e.g., marriage or living with someone who provides support and more financial security) and energy (e.g., time, money and knowledge). Stress occurs when there is a loss of resources or a threat. To illustrate this idea, Hobfoll's model proposes that work-family conflicts create tension since resources (e.g., time and energy) are lost in the process of 'juggling' professional and family roles, which in turn leads to job dissatisfaction and anxiety. Difficulties arise when the requirements of one of these roles are in excess, or are unsynchronised with the resources available to meet them. Thus, the threat or even the loss of resources is associated with greater demands in work and family roles, thereby creating greater difficulty managing the work-family conflict (Fujimoto et al., 2013). Consequently, entrepreneurs who have greater difficulty in managing work-family conflicts are more likely to perform badly in their business activities (Shelton, 2006).

Buttner and Moore (1997) refer to some studies on the impact of family on women's career. The cited authors begin by pointing out the disproportionate share of women's responsibilities in maintaining their household relatively to men, despite the growing importance of fathers and husbands in that role. Indeed, some researchers argue that women start their own business to have greater flexibility to manage their dual responsibilities (i.e., personal/professional) better and, thus, have a more balanced life (e.g., Fierman, 1990). However, other studies have found no differences between men and women regarding the influence of their family on their career paths (e.g., Konrad and Langton, 1991; Morris, 1995).

In addition to the studies mentioned before on this double role's positive impact on the creation of businesses, another set of researchers have emerged who suggest that women entrepreneurs' struggle to manage work-family conflicts may have a negative impact on their businesses (Baines and Gelder, 2003; Rouse and Boles, 2005; Rouse and Kitching, 2006).

Burt (2000) concluded that the family is a catalyst rather than a cause. Throughout their lives, whether they are entrepreneurs or not, women have the same probability as 
men of getting married, having children, getting divorced or remarrying. However, when a woman goes through one of these events, the probability of becoming an entrepreneur increases. The family factor does not seem to predict if women become entrepreneurs or not, but rather when women will become entrepreneurs.

\subsection{Motivations}

The theme of motivations in entrepreneurship literature has followed a similar path to that of organisational psychology. In organisational psychology, motivational theories have progressed from static to dynamic (Segal et al., 2005). One of the challenges facing entrepreneurs relates to their motivations to start a business and their aspirations for its growth. Women, like men, start their businesses for various reasons: personal fulfilment, power, independence, recognition, social aspiration and creation of wealth, among others.

In the GEM 2001, Reynolds et al. (2001) note that entrepreneurship is a multifaceted phenomenon. They then add a new dynamic dimension to entrepreneurial activity, requiring an entrepreneur's characterisation' to indicate whether he was starting and growing his business to take advantage of a unique market opportunity (opportunity entrepreneurship) or because it was the best option available (necessity entrepreneurship)' [Reynolds et al., (2001), p.4]. In relation to this dichotomy, researchers can also consider the classification adopted by Minitti et al. (2005). On the one hand, the cited authors classify entrepreneurs as opportunity entrepreneurs if they recognise a business opportunity and start to exploit it. On the other hand, entrepreneurs are classified as necessity entrepreneurs when they are 'pushed' into entrepreneurship because they are unemployed or dissatisfied with their current employment and see entrepreneurship as a way out or a change.

Women start their entrepreneurial activity for a myriad of reasons, such as needs and opportunities, as mentioned previously, but also because of other factors that fall within what has been termed a 'push and pull' dichotomy. In 1986, Gilad and Levine presented this theoretical model to explain entrepreneurial motivations. The push theory emphasises that individuals are 'pushed' into entrepreneurship by negative external forces, such as employment dissatisfaction, difficulty finding a job, salary dissatisfaction or rigid schedules. The pull theory states that individuals are 'attracted' to entrepreneurship because of a need for independence, recognition of a business opportunity, a need for personal development and a desire to create wealth, among other positive factors. Some researchers, including Orhan and Scott (2001), suggest that pull factors are more decisive for an individual to become an entrepreneur than push factors.

In empirical studies involving women entrepreneurs, there is no consensus on which push or pull motivational factors predominate. For example, studies conducted by Hisrich and Brush (1985) and Stokes et al. (1995) led to the conclusion that, unlike for men, push factors are predominant for women entrepreneurs, such as frustration and discomfort in their former jobs and situations in which women at a certain professional threshold did not progress to senior positions (e.g., a 'glass ceiling'). Larwood and Gattiker (1989) suggest that the study of women's career paths cannot be correctly understood when these are judged against the standards of men's careers. The cited authors further report that men usually prioritise their professional career, whereas women have to balance their energy expenditure between work and family life. On the other hand, some researchers suggest that female motivations to start a business have more similarities than differences when compared to men's, such as the propensity for risk (Masters and Maier, 
Why do some women micro-entrepreneurs decide to formalise their businesses? 247

1988), entrepreneurial values (Fagenson, 1993) and character attributes (Sexton and Bowman-Upton, 1990). Nevertheless, Buttner and Moore (1997) conclude that women entrepreneurs who start their own business are motivated mainly by pull factors, such as the desire for greater challenges and opportunities for self-determination. Their data suggests that, to these women, regardless of profits, personal fulfilment is their most important motivation.

Maysami and Goby (1999) report that, in general, women are more motivated by the need for independence, the desire for personal achievement, the recognition of others and the use of their knowledge and skills to continue their training or work experience. Noble (1986) suggests that women see in their decision to start a business not a career but a life-long strategy. Diaz-Garcia (2000) points out that the act of creating a business entails significant changes in women's lives, pushing them to meet other social agents, find solutions to their needs and solve new problems, among other challenges. All this allows them to gain security and self-confidence, play an important role in their community, contribute financially to their family and feel fulfilled. In order for women to take on an endeavour, they must put themselves to the test through a variety of decisions, choices and problems/solutions, whose success is determined by their personal abilities. This possibility of putting themselves to the test leads them to discover facets of themselves hitherto unsuspected - representing the greatest achievement to which women's activities may lead.

In addition to motivations for undertaking challenges, there are other factors that influence the levels of entrepreneurial participation and the types of business established. Thus, researchers can refer to other factors such as education, literacy and time management when meeting domestic and social responsibilities (Carter and Shaw, 2006) - issues that are discussed in the following sub-section.

\subsection{Types of women entrepreneurs}

Watkins and Watkins (1986) found that the backgrounds and experiences of women differ substantially from those of men. The cited authors report that men who start their business are more likely to rely on previous experience related to establishing independence and autonomy. In contrast, women have no previous experience to give them the expertise to create their own business, especially in sectors considered non-traditional. Thus, the cited authors concluded that women's lack of previous experience affects their choices in the business sector, forcing them to start activities in sectors traditionally assigned to women. These authors also stress that most women are not fully prepared to start a business, thus forcing them to assume many additional risks. The choice of sector by women entrepreneurs is largely determined by the selection of activities considered less risky, presenting fewer obstacles to their success.

In this context, Goffee and Scase (1985) discuss a typology of female entrepreneurs based on two factors:

1 their commitment to conventional ideas about women entrepreneurs through individualism and self-reliance

2 their unwillingness to accept conventions about gender roles usually attributed to men. From this taxonomy, four profiles of women entrepreneurs emerge.

They may be: 
1 'conventional', greatly committed to entrepreneurial ideals and conventional gender roles

2 'innovative', with a strong sense of ideal entrepreneurship but a weak connection to traditional gender roles

3 'domestic', organising their working lives around family life but strongly linked to traditional gender roles and weaker aspects of ideal entrepreneurs

4 'radical', with little connection to entrepreneurial ideals and traditional gender roles - regularly organising their businesses on a political and collectivist basis.

\section{$2.5 \quad I M E s$}

An entrepreneur is a 'restless being, aspiring to create something new or not to conform to the way things are' [GEM, (2010), p.27]. To encourage this new model of economic development, incentives have been given to individuals who represent the entrepreneurial population seeking to create enterprises (European Commission, 2002). In Brazil, these incentives evolved into a proposal that offers fair opportunities for IMEs, guaranteeing differential treatment of small businesses with the application of Supplementary Law $123 / 06$, known as the general law of micro and small enterprises. Therefore, IMEs are the individuals that benefit from this movement. Since 2009, firms with an annual income of up to $\mathrm{R} \$ 36,000$ have had their legal formalisation facilitated by filling in a single form on an Internet website (SEBRAE, 2012).

The appearance of legalised IMEs results from intensive efforts by the Brazilian service of support for micro and small enterprises to ensure greater sustainability for small businesses by providing a way out of the informal economy (SEBRAE, 2012). In order to facilitate the opening of new businesses and attract entrepreneurs to legal formality - ensuring benefits at low cost - Supplementary Law 123/06 was amended, giving way to Supplementary Law 128/08, which guarantees a specific tax regime, welfare and economic and social inclusion (SEBRAE, 2011).

The support for new entrepreneurs continued to grow and, in 2011, Supplementary Law 139/2011 was approved: this legislation's improvements include almost duplicating the IMEs' annual limit of turnover (SEBRAE, 2012). According to this law, to formalise an enterprise, the company has to fall within certain prerequisites (i.e., income of up to $\mathrm{R} \$ 60,000.00$ per year, no participation as a partner or owner of another company, an individual worker or, at the most, one additional employee and no branch office). The entire registration process can be accomplished online.

\subsubsection{Brazilian IMEs: short characterisation}

According to the GEM (2012), of the total established entrepreneurs, $57.8 \%$ are male and $42.2 \%$ are female. These data differ from that of the first entrepreneurs who included more women in the labour market, with $52.2 \%$ female versus $47.8 \%$ male entrepreneurs. This means that, even though these figures are close, on the one hand, the rate of women starting their own business is higher, and, on the other hand, men can keep their businesses going for a longer time. 
Regarding their distribution by Brazilian state, IMEs concentrate more in the southeast, but with significant numbers in the south and northeast: São Paulo (23.7\%), Rio de Janeiro (12.4\%), Minas Gerais (10.1\%), Bahia (7.7\%) and Rio Grande do Sul (5.6\%) (SEBRAE, 2012). Table 2 shows which activities were the most popular among women IMEs in Vitória da Conquista, Bahia, in 2013.

Table 2 Women IMEs in Vitoria da Conquista: main activities

\begin{tabular}{lc}
\hline Activities & Women IMEs \\
\hline Retailer - clothing and accessories & 647 \\
Hairdresser & 406 \\
Clothing tailor (except underwear) & 150 \\
Retailer - minimarket, grocery store or warehouse & 137 \\
Retailer - cosmetics, perfumery and personal care products & 133 \\
Other beauty treatment activities & 126 \\
Bar manager or manager of another establishment serving drinks & 111 \\
\hline
\end{tabular}

\section{Methodology}

A questionnaire was distributed to IMEs listed in the Vitória da Conquista unit of SEBRAE, during the income tax declaration filing period. The data were collected using this instrument from women owners of micro-enterprises operating in both rural and urban areas, regardless of their business activity. The questionnaire's design reflected many of the research concerns raised, and survey instruments used, in previous research: profile (Kirzner, 1979; Baron, 2004; Tang et al., 2007; Marques et al., 2011b), motivation (Cromie, 1987; Buttner and Moore, 1997; Caputo and Kolinsky, 1998; Diaz-Garcia, 2000; Marques et al., 2011b), women's dual role (Kahn et al., 1964; Cromie and Hayes, 1988; Marques et al., 2011a) and motivations to formalise businesses (SEBRAE, 2013). Three quarters of the items had been tested and validated in Marques et al.'s (2011b) study, and the rest were validated in a SEBRAE (2013) study.

The questionnaire was designed, tested and distributed in the first trimester of 2014 to women who used the Vitória da Conquista SEBRAE in Bahia, Brazil to formalise their micro business. This instrument requested information regarding:

1 their company's main characteristics

2 the respondents' personal details

3 their motivations to start or formalise their business

4 their perceptions of work-family balance

5 their psychological and cognitive profile. The data were elicited using predominantly multiple choice questions using a five-point Likert scale.

A total of 154 businesswomen were surveyed.

We evaluated various multiple linear regression models to assess the contribution of psychological variables to explaining the variance of motivations and work-family 
balance perceptions. The profiles of individual entrepreneurs were determined by a cluster analysis.

\subsection{Characteristics of the sample}

The sample had an average age of 38.65 years ( $\mathrm{SD}=9.88$ years), making the respondents comparable to their counterparts worldwide (GEM, 2011). Almost two-thirds $(61.3 \%)$ of respondents were married and $78.5 \%$ have sons. About three-quarters $(72.2 \%)$ had attended elementary and secondary school - without necessarily completing their studies - but only $9.8 \%$ had a university degree. Notably, $55.2 \%$ of these entrepreneurs ran their company from their residence. Most firms (98.6\%) were service providers or retailers.

\section{Results}

A cluster analysis was used to divide the sample into homogeneous groups, using psychological variables, motivations and perceptions of work-family balance as classification criteria, and to profile the women in the resulting clusters. To produce the clusters, we used the complete-linkage method, computing the distance between clusters as the distance between the two instances that are farthest away from each other. Based on Goffee and Scase's (1985) theory, we describe three clusters of entrepreneurial women below (see Table 3).

Table 3 Analysis of clusters defining entrepreneurial women's profile

\begin{tabular}{|c|c|c|}
\hline Cluster 1 & Cluster 2 & Cluster 3 \\
\hline Innovative & Domestic & Conventional \\
\hline+ Initiative & + Self-confidence & $\begin{array}{c}\text { Autonomy predisposition to } \\
\text { risk }\end{array}$ \\
\hline - Family influence & - Professional growth & $\begin{array}{l}+ \text { Personal and financial } \\
\text { fulfilment }\end{array}$ \\
\hline $\begin{array}{l}+ \text { Management of time and } \\
\text { responsibilities }\end{array}$ & $\begin{array}{c}+ \text { Personal and professional } \\
\text { satisfaction }\end{array}$ & $\begin{array}{l}\text { - Married or in a stable } \\
\text { relationship }\end{array}$ \\
\hline- Age & + Interference in personal life & + Children \\
\hline+ Not married & $\begin{array}{l}\text { + Married or in a stable } \\
\text { relationship }\end{array}$ & + Secondary school \\
\hline - Children & + Children & $\begin{array}{l}\text { + Company run from } \\
\text { residence }\end{array}$ \\
\hline + Higher education & - Education & \\
\hline $\begin{array}{l}\text { + More flexible working } \\
\text { hours }\end{array}$ & $\begin{array}{l}\text { + Company run from } \\
\text { residence }\end{array}$ & \\
\hline
\end{tabular}

Cluster one can be labelled 'innovative entrepreneurs', given their higher averages in the psychological traits related to initiative. This cluster is essentially concerned with how these women established priorities in time management and responsibilities when reflecting on their double role (i.e., family vs. work). They distinguish themselves from other women micro-entrepreneurs due to their motivation of financial advantages when they began their entrepreneurial initiative. 
Cluster two contains 'domestic entrepreneurs' who stand out for their higher average in terms of self-confidence, creativity and innovation. The interference of work in their personal life is a factor they consider in regards to their double role. In cluster two, social and personal benefits are a strong motivation for the formalisation of their business. This group is also characterised by a greater influence of family in the creation of their own business.

Cluster three corresponds to 'conventional entrepreneurs'. This group is less susceptible to risk. They paid particular attention to the bureaucratic and accounting advantages when formalising their business, and pursued personal growth, personal and material fulfilment and professional development at the time of their business's creation.

Overall, the first cluster of innovative entrepreneurs are characterised by a lower age average, no marriage, a higher level of education, fewer children, greater support from domestic workers and a more flexible work schedule. This is in contrast to domestic entrepreneurs, who are characterised by a more advanced age, for not running their business from their home and by a lower level of education. The latter group is also characterised by having children, more structured schedules and less support from domestic workers. Most of cluster three's conventional entrepreneurs have a company they run from their home, a more structured schedule, more children and an intermediate level of education, as well as being married or in a stable relationship.

Regarding the characterisation of their businesses, innovative entrepreneurs reported that they requested assistance from family members to start their business, even at a time when public funding was available. Opportunity proved to be an important reason these women created their entrepreneurial initiative. Domestic entrepreneurs are the ones who most often hold on to another professional activity, in addition to their business. This group presented a higher number of SEBRAE requests for help for a considerable initial investment, which was not drawn, for the most part, from their own savings, but instead from loans and funds. Compared to the other two groups, necessity is a stronger reason why they chose to formalise their company.

Conventional entrepreneurs are characterised by not having previously formalised their business activities. Because these women are more exclusively dedicated to their business, they also invest higher amounts and make a wider use of their own savings. Opportunity was the fundamental reason they formalised their firm.

As Goffee and Scase (1985) suggested, these women's life styles can also be characterised as innovative, domestic and conventional. Innovative entrepreneurs are characterised by a higher level of education and lower level of concern about family. Domestic entrepreneurs are older and have a lower level of education. Regarding their double role, as noted by Marques et al. (2011b), we found that domestic and conventional entrepreneurs are married or in stable unions with children, so they express greater concern for their family's well-being. These two types of entrepreneurs are those who have the largest number of children and, at the most, an intermediate level of education.

\subsection{Motivation for business formalisation}

At this point, we analysed what shaped the participants' motivations to formalise a business by looking at the results of the linear regression analysis assessing the contribution of cognitive and psychological traits and work-family balance, in order to explain these women's motives for formalising their business. In Table 4, we also present the coefficients of the independent variables by a stepwise regression. 
Table 4 Motivations for business formalisation based on psychological profile

\begin{tabular}{lcccccc}
\hline $\begin{array}{l}\text { Motivations for } \\
\text { formalisation of } \\
\text { business }\end{array}$ & $\begin{array}{c}\text { Psychological profile } \\
\text { traits that contribute } \\
\text { significantly }\end{array}$ & $\beta$ & $\begin{array}{c}\beta \\
\text { standardised }\end{array}$ & Sig. & $\begin{array}{c}R 2 \\
\text { adjusted }\end{array}$ & $F$ \\
\hline $\begin{array}{l}\text { Bureaucratic and } \\
\begin{array}{l}\text { accounting } \\
\text { benefits }\end{array}\end{array}$ & $\begin{array}{c}\text { Capacity for } \\
\text { initiative }\end{array}$ & 0.298 & 0.215 & $\mathrm{p}<0.05$ & 0.040 & 6.330 \\
$\begin{array}{l}\text { Social and } \\
\text { personal benefits }\end{array}$ & Autonomy & 0.268 & 0.189 & $\mathrm{p}<0.05$ & 0.028 & 4.835 \\
\hline
\end{tabular}

Notes: Regression equations: bureaucratic and accounting benefits $=2.523+$ (capacity for initiative $\times 0.298$ ), social and personal benefits $=2.802+$ (autonomy $\times 0.268)$.

The capacity for initiative proved to be a psychological trait with a positive and statistically significant contribution to the motivation of bureaucratic and accounting advantages. When seeking to obtain social and personal benefits, autonomy proved to have a positive and statistically significant contribution.

\subsection{Work-family balance}

Similar to what was done with motivations; we examined psychological traits that are important factors in predicting the double role of entrepreneurs. The results are shown in Table 5.

Table 5 Work-family balance depending on psychological profile

\begin{tabular}{lcccccc}
\hline $\begin{array}{l}\text { Work-family } \\
\text { balance }\end{array}$ & $\begin{array}{c}\text { Psychological profile traits } \\
\text { that contribute } \\
\text { significantly }\end{array}$ & $\beta$ & $\begin{array}{c}\beta \\
\text { standardised }\end{array}$ & Sig. & $\begin{array}{c}\text { R2 } \\
\text { adjusted }\end{array}$ & $F$ \\
\hline $\begin{array}{l}\text { Interference } \\
\text { in personal }\end{array}$ & Creativity and innovation & 0.799 & 0.844 & $\mathrm{p}<0.001$ & 0.761 & 141.143 \\
life & Capacity for initiative & 0.136 & 0.143 & $\mathrm{p}<0.001$ & & \\
$\begin{array}{l}\text { Personal and } \\
\text { Predisposition to take risks }\end{array}$ & -0.056 & -0.116 & $\mathrm{p}<0.05$ & & \\
Selfily & Self-confidence & 0.482 & 0.377 & $\mathrm{p}<0.001$ & 0.136 & 21.708 \\
\hline
\end{tabular}

Notes: Regression equations: interference in personal life $=0.620+($ creativity and innovation $\times 0.799)+($ capacity for initiative $\times 0.136)+($ predisposition to risk $\times$ $-0.056)$, personal and family harmony $=2.064+($ self-confidence $\times 0.482)$

Creativity and innovation play a major role in explaining the interference of work in these women's personal life. This dimension of balance is also modestly influenced (positively) by a capacity for initiative and (negatively) by a predisposition to taking risks. On the other hand, self-confidence has a positive effect on personal and family harmony.

\section{Conclusions}

Female entrepreneurship is increasingly recognised as a key factor in many countries' economic growth (e.g., Marques et al., 2011a; Ramadani et al., 2013; Welsh et al., 2014; Tlaiss, 2015). Business start-ups create new jobs for men and women, particularly in 
growing economies, as has been the case recently in Brazil. With the ever increasing influx of women into the labour force, entrepreneurship is a welcome opportunity for women to earn their own income while also helping others to do this. However, despite the promising prospects of economic activities, quantitative information on the profiles of individual women micro-entrepreneurs was lacking, particularly in relation to their motivations for formalising their businesses. This study was undertaken to fill in this information gap.

The results suggest that women in Vitória da Conquista opt for legalised individual entrepreneurship in order to access social, fiscal and financial benefits, as evidenced by the GEM (2011) survey, which reported noticeable advantages for formalised businesses' performance. The cited survey found that $55 \%$ of respondents saw an increase in revenue, $52 \%$ reported greater control of finances, $54 \%$ highlighted an increase in investments and $26 \%$ reported an increase in sales to other companies (GEM, 2011).

Regarding the profile of individual female entrepreneurs in Vitória da Conquista, based on cluster analysis, these women can be classified as innovative, domestic and conventional (Goffee and Scase, 1985). Innovative entrepreneurs are characterised by a higher level of education and less concern about their family. Domestic entrepreneurs are older, and they have a lower level of education. Regarding duplication of roles, it was found that domestic and conventional entrepreneurs are married or in stable unions with children and that these women express more concern about their family (Marques et al., 2011a). Conventional entrepreneurs are those with the largest number of children and an intermediate level of education. Other features were identified in relation to the profile of enterprising women, using an analysis of psychological factors. Thus, the following psychological traits characterising women entrepreneurs were found in this study: initiative, autonomy, creativity and self-confidence. These results support Hisrich et al. (2014) and Kourilsky's (1980) findings.

There are two types of motivation to start one's own enterprise: negative/external push factors (e.g., poor career/promotion prospects and family economic pressures) and positive/internal pull factors (e.g., the desire to achieve personal fulfilment and social status and to create wealth, as well as the need for new challenges). In line with Buttner and Moore's (2007) results, the Brazilian women entrepreneurs surveyed were more motivated by pull factors.

The results of the multiple linear regression models used show that entrepreneurial profiles influence motivations to formalise businesses. The capacity for initiative is a psychological trait with a positive correlation with bureaucratic and accounting benefits of formalising a business. Autonomy has a positive relationship with obtaining social and personal benefits from formalising a business (McClelland, 1961).

Women entrepreneurs' profiles influence their work-family balance as well. Hence, it appears that issues related to the interference of work in their personal life are explained by traits such as creativity and innovation, while facets related to person and family harmony are explained by entrepreneurial self-confidence, which is in line with McClelland's (1961) findings.

This empirical study was motivated by the question of why some women micro-entrepreneurs decide to join the formal economy. Based on this study's results, we believe our goal to contribute to the understanding of this new category of 'entrepreneurial individuals' has been achieved. In Brazil, the designing and passing of a law geared towards this type of entrepreneur (i.e., IMEs) has had a quite positive effect on the formalisation of businesses (i.e., new and existing firms). Other developing 
economies - and even developed ones - need to keep in mind the positive effects of this approach and apply it as a good method to reduce the percentage represented by the informal economy.

Our research attempted to contribute to filling the gap in the literature identified by Shelton (2006) and DeMartino et al. (2006) concerning formal business-related activities and the balance between work and family life of women micro-entrepreneurs. To be able to measure the importance of these effects more accurately, a more balanced sample of dual- and single-role businesswomen would have to be constructed.

In addition to disaggregating and modelling some of the components of woman entrepreneurs' dual roles as 'home-maker' and 'profit-maker', complementary studies of a more qualitative nature could be undertaken. These would enrich and deepen the contemporary narrative relating to the ostensibly 'background' role that family responsibilities play in motivating business formalisation and, consequently, conditioning or inhibiting formal female entrepreneurship.

\section{Acknowledgements}

This work is supported by national funds provided by the FCT - the Portuguese Foundation for Science and Technology, through its project UID/SOC/04011/2013.

\section{References}

Ahl, H. (2004) The Scientific Reproduction of Gender Inequality: A Discourse Analysis of Research Texts on Women's Entrepreneurship, Liber, Copenhagen Business School Press, Sweden.

Babbitt, L.G., Brown, D. and Mazaheri, N. (2015) 'Gender, entrepreneurship, and the formalinformal dilemma: evidence from Indonesia', World Development, Vol. 72, pp.163-174.

Baines, S. and Gelder, U. (2003) 'What is family friendly about working in the home? The case of self-employed parents and their children', New Technology, Work and Employment, Vol. 18, No. 13, pp.224-234.

Baron, R. (2004) 'Potential benefits of the cognitive perspective: expanding entrepreneurship's array of conceptual tools', Journal of Business Venturing, Vol. 19, No. 2, pp.169-172.

Bruin, A., Brush, C.G. and Welter, F. (2007) 'Advancing a framework for coherent research on women's entrepreneurship', Entrepreneurship Theory and Practice, Vol. 31, No. 3, pp.323-339.

Brush, C., Bruin, A. and Welter, F. (2009) 'A gender-aware framework for women's entrepreneurship', International Journal of Gender and Entrepreneurship, Vol. 1, No. 1, pp.8-24.

Brush, C.G. (1992) 'Research on women business owners: past trends, a new perspective and future directions', Entrepreneurship, Theory and Practice, Vol. 16, No. 4, pp.5-30.

Burt, R. (2000) Creating Careers: Women's Paths through Entrepreneurship, Graduate School of Business, University of Chicago, Chicago.

Buttner, E.H. and Moore, D.P. (1997) 'Women's organisational exodus to entrepreneurship: self-reported motivations and correlates with success', Journal of Small Business Management, Vol. 35, No. 1, pp.34-46.

Caputo, R.K. and Dolinsky, A. (1998) 'Women's choice to pursue self-employment: the role of financial and human capital of household members', Journal of Small Business Management, Vol. 36, No. 3, pp.8-17. 
Why do some women micro-entrepreneurs decide to formalise their businesses? 255

Carland, J.A.C. and Carland, J.W. (1991) 'An empirical investigation into the distinctions between male and female entrepreneurs and managers', International Small Business Journal, Vol.9, No.3, pp.62-72.

Carter, S. and Shaw, E. (2006) Women's Business Ownership: Recent Research and Policy Developments, Report to the Small Business Service.

Carter, S., Anderson, S. and Shaw, E. (2001) Women's Business Ownership: A Review of the Academic, Popular and Internet Literature, Report to the Small Business Service.

Cromie, S. (1987) 'Motivations of aspiring male and female entrepreneurs', Journal of Occupational Behaviour, Vol. 8, No. 3, pp.251-261.

Cromie, S. and Hayes, J. (1988) 'Towards a typology of female entrepreneurs', Sociological Review, Vol. 36, No. 1, pp.87-113.

DeMartino, R., Barbato, R. and Jacques, P.H. (2006) 'Exploring the career/achievement and personal life orientation differences between entrepreneurs and nonentrepreneurs: the impact of sex and dependents', Journal of Small Business Management, Vol. 44, No. 3, pp.350-368.

Diaz-Garcia, M.C. (2000) La iniciativa empresarial femenina. Universidad de Castilla La Mancha, Facultad de Ciências Económicas y Empresarialesl, Série 10, No. 2.

European Commission (2002) Good Practices in the Promotion of Female Entrepreneurship: Examples from Europe and other OECD Countries, European Commission, Enterprise Directorate General and Austrian Institute for Small Business Research, Brussels.

Fagenson, E.A. (1993) 'Personal value-systems of men and women entrepreneurs versus managers', Journal of Business Venturing, Vol. 8, No. 5, pp.409-430.

Fierman, J. (1990) 'Why women still don't hit the top', Fortune, Vol. 122, No. 3, pp.40-62.

Ford, M.T., Heinen, B.A. and Langkamer, K.L. (2007) 'Work and family satisfaction and conflict: a meta-analysis of cross-domain relations', Journal of Applied Psychology, Vol. 92, No. 1, pp.57-80.

Fujimoto, Y., Azmat, F. and Härtel, C.E.J. (2013) 'Gender perceptions of work-life balance: management implications for full-time employees in Australia', Australian Journal of Management, Vol. 38, No. 1, pp.147-170.

Gatewood, E.J., Brush, C.G., Carter, N.M., Greene, P.G. and Hart, M.M. (2009) 'Diana: a symbol of women entrepreneurs' hunt for knowledge, money, and the rewards of entrepreneurship', Small Business Economics, Vol. 32, No. 2, pp.129-144.

GEM (2010) Empreendedorismo no Brasil: 2010/Simara Maria de Souza Silveira Greco et al., IBQP, Curitiba.

Gilad, B. and Levine, P. (1986) 'A behavioral model of entrepreneurial supply', Journal of Small Business Management, Vol. 24, No. 4, pp.45-53.

Global Entrepreneurship Monitor (GEM) (2011) Empreendedorismo no Brasil: Relatório Executivo, IBQP, Curitiba.

Global Entrepreneurship Monitor (GEM) (2012) Empreendedorismo no Brasil: 2012, IBQP, Curitiba.

Global Entrepreneurship Monitor (GEM) (2013) Empreendedorismo no Brasil: 2013, IBQP, Curitiba.

Goffee, R. and Scase, R. (1985) Women in Charge: The Experiences of Female Entrepreneurs, George Allen and Unwin, London

Greene, P.G., Hart, M.M., Gatewood, E.J., Brush, C.G. and Carter, N.M. (2003) Women Entrepreneurs: Moving Front and Center: An Overview of Research and Theory, Coleman White Paper Series, No. 3, pp.1-47.

Henry, C. (2007) 'Women entrepreneurs', in C. Wankel (Ed.): 21st Century Management. A Reference Handbook, pp.51-59, Sage, Thousand Oaks.

Henry, C., Foss, L. and Ahl, H. (2015) 'Gender and entrepreneurship research: a review of methodological approaches', International Small Business Journal, DOI: 10.1177/ 0266242614549779 . 
Hisrich, R. (1989) Entrepreneurship: Starting, Developing and Managing A New Enterprise, BPI, Irwin, Boston.

Hisrich, R. and Brush, C.G. (1984) 'The woman entrepreneur: management skills and business problems', Journal of Small Business Management, Vol. 22, No. 1, pp.30-37.

Hisrich, R.D. and Brush, C.G. (1985) 'Women and minority entrepreneurs: a comparative analysis', in Hornaday, J.A., Shils, E.B., Timmons, J.A. and Vesper, K.H. (Eds.): Frontiers of Entrepreneurship Research, pp.566-587, Babson Center for Entrepreneurial Studies, Wellesley, Massachusetts.

Hisrich, R.D. and O'Brien, M. (1982) 'The woman entrepreneur as a reflection of the type of business', in Vesper, K.H. (Ed.): Frontiers of Entrepreneurial Research, pp.54-67, Babson College, Wellesley, MA.

Hisrich, R.D. and Peters, M.P. (2004) Empreendedorismo, 5th ed., Bookman, Porto Alegre.

Hisrich, R.D., Peters, M.P. and Shepherd, D.A. (2014) Empreendedorismo, McGraw Hill, Brasil.

Hobfoll, S.E. (1989) 'Conservation of resources', American Psychologist, Vol. 44, No. 3, pp.513-524.

Holmquist, C. and Carter, S. (2009) 'The diana project: pioneering women studying pioneering women', Small Business Economics, Vol. 32, No. 2, pp.121-128.

Hughes, K.D., Jennings, J.E., Brush, C., Carter, S. and Welter, F. (2012) 'Extending women's entrepreneurship research in new directions', Entrepreneurship Theory and Practice, Vol. 36, No. 3, pp.429-442.

Kahn, R., Wolfe, D., Quinn, R., Snoek, J. and Rosenthal, R. (1964) Organisational Stress: Studies in Role Conflict and Ambiguity, John Wiley, Oxford, England.

Kirzner, I.M. (1979) Perception, Opportunity, and Profit: Studies in the Theory of Entrepreneurship, University of Chicago Press, Chicago.

Konrad, A. and Langton, N. (1991) 'Sex differences in job preferences, workplace segregation, and compensating earning differentials: the case of Stanford MBAs', in Wall, J. and Jauch, L. (Ed.): Proceedings of Academy of Management Meetings, pp.368-371, Miami Beach.

Kourilsky, M.L. (1980) 'Predictors of entrepreneurship in a simulated economy', Journal of Creative Behavior, Vol. 14, No. 3, pp.175-199.

Larwood, L. and Gattiker, U. (1989) 'A comparison of the career paths used by successful men and women', in Gutek, B. and Larwood, L. (Eds.): Women's Career Development, pp.129-156, Sage Publications, Newbury, Park, California.

Lee-Gosselin, H. and Grise, J. (1990) 'Are women owner-managers challenging our definitions of entrepreneurship? An In-depth study', Journal of Business Ethics, Vol. 9, Nos. 4/5, pp.423-433.

Marlow, S. (1997) 'Self-employed women - new opportunities, old challenges?', Entrepreneurship and Regional Development, Vol. 9, No. 3, pp.199-210.

Marques, C., Santos, G., Gerry, C. and Gomes, G. (2011a) 'Business motivation and work-family balance among urban and rural women entrepreneurs in Portugal', in R. Fairchild (Ed.): Entrepreneurship: Motivation, Performance and Risk Reward, pp.167-191, Nova Science, New York.

Marques, C.S., Ferreira, J., Rodrigues, R.G. and Ferreira, M. (2011b) 'The contribution of yoga to the entrepreneurial potential of university students: a SEM approach', International Entrepreneurship and Management Journal, Vol. 7, No. 2, pp.255-278.

Masters, R. and Meier, R. (1988) 'Sex differences and risk-taking propensity of entrepreneurs', Journal of Small Business Management, Vol. 26, No. 1, pp.31-35.

Maysami, R.C. and Goby, P.G. (1999) 'Female business owners in Singapore and elsewhere: a review of studies', Journal Small Business Management, Vol. 37, No. 2, pp.96-105.

McClelland, D. (1961) The Achieving Society, Van Nostrand, Princeton, New Jersey. 
Minitti, M., Arenius, P. and Langowitz, N. (2005) Global Entrepreneurship Monitor: 2004 Report on Women and Entrepreneurship, Babson College and London Business School, Babson Park, MA and London.

Morris, B. (1995) 'Executive women confront mid-life crisis', Fortune, Vol. 132, No. 6, pp.60-72.

Noble, B.P. (1986) 'Women entrepreneurs: the new business owners/a sense of self', Venture, Vol. 8, No. 7, pp.33-36.

Organisation for Economic Co-operation and Development (OECD) (1998) Women Entrepreneurs in SMEs: A Major Force in Innovation and Job Creation, Synthesis, Paris.

Orhan, M. and Scott, D. (2001) 'Why women enter into entrepreneurship: an explanatory model', Women in Management Review, Vol. 16, Nos. 5/6, pp.232-243.

Ramadani, R., Gërguri, S., Dana, L.P. and Tašaminova, T. (2013) 'Women entrepreneurs in the Republic of Macedonia: waiting for directions', International Journal of Entrepreneurship and Small Business, Vol. 19, No. 1, pp.95-121.

Raposo, M., Paço, A. and Ferreira, J. (2008) 'Entrepreneurs's profile: a taxonomy of attributes and motivations of university students', Journal of Small Business and Enterprise Development, Vol. 15, No. 2, pp.405-418.

Reynolds, P.D., Camp, S.M., Bygrave, W.D., Autio, E. and Hay, M. (2001) Global Entrepreneurship Monitor 2001 Executive Report, Babson College, London Business School, London.

Rouse, J. and Boles, K. (2005) The Big NES Survey 2004: An Evaluation of the Experiences of New Entrepreneur Scholars, National Federation of Enterprise Agencies/Learning and Skills Council, Bedford.

Rouse, J. and Kitching, J. (2006) 'Do enterprise support programmes leave women holding the baby?', Environment and Planning C: Government and Policy, Vol. 24, No. 1, pp.5-19.

Schreier, J. (1975) The Female Entrepreneur: A Pilot Study, Center for Venture Management, Milwaukee, Wis.

Schumpeter, J. (1942) Capitalism, Socialism and Democracy, Harper and Brothers, Nueva York.

Schwartz, E.B. (1976) 'Entrepreneurship: a new female frontier', Journal of Contemporary Business, Vol. 5, No. 1, pp.47-76.

Segal, G., Borgia, D. and Schoenfeld, J. (2005) 'The motivation to become an entrepreneur', International Journal of Entrepreneurial Behaviour and Research, Vol. 11, No. 1, pp.42-57.

Serviço Brasileiro de apoio a pequena empresa (SEBRAE) (2011) Perfil do Microempreendedor Individual 2011, DF, Brasilia.

Serviço Brasileiro de apoio a pequena empresa (SEBRAE) (2012) Perfil do Microempreendedor Individual 2012, DF, Brasilia.

Serviço Brasileiro de apoio a pequena empresa (SEBRAE) (2013) Caderneta do Microempreendedor Individual, Salvador, BA.

Serviço Brasileiro de apoio a pequena empresa (SEBRAE) (2014) Levantamento do número total de Microeemprededores Individuaus na Bahia, Fevreiro 2010 a Dezembro de 2013, Período.

Sexton, D. and Bowman-Upton, N. (1990) 'Female and male entrepreneurs: psychological characteristics and their role in gender-related discrimination', Journal of Business Venturing, Vol. 5, No. 1, pp.29-36.

Sexton, D.L. and Bowman, N. (1986) 'Validation of a personality index: comparative psychological characteristics analysis of female entrepreneurs, managers, and entrepreneurship students and business students', in Ronstadt, R., Hornaday, J., Peterson, R. and Vesper, K. (Eds.): Frontiers of Entrepreneurship Research, Babson College, Wellesley, MA.

Sexton, D.L. and Kent, C.A. (1981) 'Female executives and entrepreneurs: a preliminary comparison', in Vesper, K.H. (Ed.): Frontiers of Entrepreneurship Research, pp.40-55, Babson College, Wellesley, MA. 
Shaver, K.G., Gartner, W.B., Gatewood, E.J. and Vos, L.H. (1996) 'Psychological factors in success at getting into business', in P. Reynolds, S. Birley, J.E. Butler, W.D. Bygrave, P. Davidsson, W.B. Gartner and P.P. McDougall (Eds.): Frontiers of Entrepreneurship Research, pp.77-90, Babson College, Babson Park, MA.

Shelton, L.M. (2006) 'Female entrepreneurs, work-family conflict, and venture performance: new insights into the work-family interface', Journal of Small Business Management, Vol. 44, No. 2, pp.285-297.

Stokes, J., Riger, S. and Sullivan, M. (1995) 'Measuring perception of the working environment for women in corporate settings', Psychology of Women Quarterly, Vol. 19, No. 4, pp.533-549.

Tang, J., Tang, Z. and Lohrke, F. (2007) 'Developing an entrepreneurial typology: the roles of entrepreneurial alertness and attributional style', The International Entrepreneurship and Management Journal, Vol. 4, No. 3, pp.273-294.

Tlaiss, H.A. (2015) 'How Islamic business ethics impact women entrepreneurs: insights from four Arab Middle Eastern countries', Journal of Business Ethics, Vol. 129, No. 4, pp.859-877.

Watkins, J.M. and Watkins, D.S. (1986) 'The female entrepreneur: her background and determinants of business chaos - some British data', in Curran, J., Stanworth, J. and Watkins, D. (Eds.): The Survival of the Small Firm Volume 1: The Economics of Survival and Entrepreneurship, Gower Publishing, Aldershot.

Welsh, D.H., Memili, E., Kaciak, E. and Ochi, M. (2014) 'Japanese women entrepreneurs: implications for family firms', Journal of Small Business Management, Vol. 52, No. 2, pp.286-305.

Zhao, H. and Seibert, S.E. (2006) 'The big five personality dimensions and entrepreneurial status: a meta-analytical review', Journal of Applied Psychology, Vol. 91, No. 2, pp.259-271. 